\title{
Application of Digital Infrared Thermographic Imaging (DITI) in the Monitoring of Change of Skin Temperature about Vascular Supply of Lower Abdominal Axial Flap in the Rabbit
}

Hyun nam Choi, Jin Hyung Park, Yea Sik Han, Sin Rak Kim, Han Kyeol Kim

Department of Plastic and Reconstructive Surgery, College of Medicine, Kosin University, Busan, Korea

\section{가토의 하복부 축성 피판의 생존 예후 평가를 위한 컴퓨터 적외선 체열 감지기의 유용성}

최현남·박진형·한예식·김신락·김한결

고신대학교 복음병원 성형외과

Objectives: Monitoring viability of flap is important. The flap survival depends on the vascularity of the flap, on which the skin temperature depends. The authors applied digital infrared thermographic imaging (DITI) for monitoring the vascular supply of the flap and for the prediction of the prognosis of the flap survival.

Methods: Eight male New Zealand white rabbits with average weight of $3 \mathrm{~kg}$ were used. A $10 \times 10 \mathrm{~cm}$ unipedicled fasciocutaneous island flap was elevated based on the left superficial inferior epigastric vessel. The surface temperatures on designed flap were checked with DITI for 24 hours after the operation. On 14th day after the operation, the surviving area was measured and compared with DITI image which was taken on 24 hours after the operation using digital analysis software Imagej. Statistical analysis was evaluated by paired T-test

Results: On DITI image 24 hours after the flap elevation, distal portion of the flap showed remarkable color change. The average percentage and the standard deviation of the survival area of the flap which is predicted by DITI and the average percentage and the standard deviation of the survival area of the flap which was actually measured 2 weeks after flap elevation were 55.3 (16.6), 56.2 (18.0), respectively. This shows no significant difference between the two.

Conclusions: This study shows that DITI system could be used in evaluation of flap vascularity with ease, quickness and safety for patient and flap. Thus, it could be used clinically for the prediction of flap survival.

Key Words: Digital infrared thermographic imaging (DITI), Flap monitoring

성형외과 영역에서 피판술은 큰 비중을 차지하고 있지 만, 혈관경의 문제로 인한 피판의 손실은 심각한 합병증을 남긴다. 술 후 피판의 생존 여부는 혈류의 공급 정도에 따라 좌우된다. 술 후 관리 시스템을 이용한 술 후 관리와 문제점의 조기 발견으로 혈관경의 문제를 성공적으로 해 결한다면 피판의 구제율을 $83 \%$ 까지 올릴 수 있다. ${ }^{2}$
피판의 생존율을 향상시키기 위해 혈관경의 혈류 상태 를 파악하여 피판의 상태를 감시하고 평가하는 방법이 많이 시도되었다. 피판의 색, ${ }^{3}{ }^{\text {온도 }}{ }^{4}$ 및 모세혈관 재충전 등의 이학적 검사와 임상 경험을 토대로 피판의 혈류 상태 를 파악할 수 있다. 그러나 피판의 색은 공여부에 따라서 차이가 날 수 있고, 피판의 온도 또한 객관적 척도가 될
Corresponding Author: Yea Sik Han, Department of Plastic Surgery, College of Medicine, Kosin University, 34 Amnam-dong, Seo-gu, Busan, 602-702, Korea

TEL: +82-51-990-6131 FAX: +82-51-990-3005 E-mail: hanplastic1@naver.com
Received: February 8, 2013

Revised: July 3, 2013

Accepted: July 23, 2013 
수 없다. ${ }^{5,6}$ 따라서 정확한 피판 혈류를 감지하기 위하여 레이저 도플러 혈류측정기(laser Doppler flowmeter), 정맥 내 형광 검사법(intraveneous fluorescein test), 정 맥 내 방사선 동위원소 관류법(intravenous radioisotope perfusion test), 광혈량계(photoplethysmography) 등 의 방법이 개발되었다. 이 방법들은 매우 정밀하고 민감하 지만 자세나 주위 환경에 의해 변화의 폭이 크고 측정방법 에 따른 민감도나 특이도의 차이가 있으며 장비가 고가이 어서 현실적으로 손쉽게 이용하기가 어려운 단점이 있 다. ${ }^{7}$

피판 혈류 상태의 변화는 피부 온도를 측정함으로서 신속하게 알아낼 수 있다. ${ }^{8}$ 피판의 혈류상태를 혈관조영 영상처럼 연속적으로 볼 수 있다면 수술 후 피판이 가지는 취약점의 조기 극복과 예방에 큰 도움이 될 수 있다.

저자들은 피판의 생존을 예상하기 위한 노력으로 피판 의 지형학적 체표온도 분포를 알 수 있는 컴퓨터 적외선 체열감지기(digital infrared thermographic imaging)를 사용하여 축성 피판의 초기 혈류량을 평가하는 것이 예후 예측에 도움이 될 것이라고 가정하였다. 연구의 목적은 술 후 체표온도의 변화에 따른 체열감지기의 영상이 피판 의 혈류량을 객관적으로 보여줄 수 있고, 피판의 생존의 예측판정에 도움을 줄 수 있다.

\section{연구대상 및 방법}

\section{1. 재료 및 수술 방법}

실험동물은 체중 2.5-3.5 kg의 New Zealand white rabbit 수컷 8마리를 사용하였다. 본 연구는 고신대학교 복음병원 동물실험윤리위원회의 승인 후 시행되었다. 실 험실의 환경은 평균 $18^{\circ} \mathrm{C}$, 습도는 $45 \%$ 였으며, 대류를 최 소한으로 줄이기 위해 실내 공기를 밀폐시켰다. 마취는 ketamine $0.25 \mathrm{~mL} / \mathrm{kg}$ 과 xylazine $0.05 \mathrm{~mL} / \mathrm{kg}$ 을 대퇴부 에 근육주사하였다. 마취 후 토끼 복부 피부를 작도할 피판 크기보다 넓게 면도하여 주위 털이 복부 체온에 미치 는 영향이 없도록 하였다. 가토의 천부 왼쪽 하복부 혈관 만을 기저로 하는 $10 \times 10 \mathrm{~cm}$ 의 도서형 근막 피부 피판을



Fig. 1. Design and elevation of fasciocutaneous island flap. (A) Preoperative marking of the flap, (B) Intraoperative view of $10 \times 10 \mathrm{~cm}$ sized left superficial inferior epigastric artery based fasciocutaneous island flap elevation.

디자인하였다. 피판 거상 시 오른쪽 천부 하복부 혈관을 결찰하여 편측 하복부 혈관을 기저로 하고 중앙선 반대편 피부 절편까지 임의 확장된 복부 피판이 만들어졌다. 임의 확장된 피판은 피판의 원위부와 혈관경 반대편의 예측 가능하며 일관된 피판 괴사를 보일 것이라는 가정 하에 디자인 되었다. ${ }^{9}$ 피판을 거상한 뒤 바닥에서부터 신생되 어 들어오는 혈류를 차단하기 위해서 polyethylene를 피 판 바닥에 깔고 피판을 다시 원위치시켜 5-0 Nylon ${ }^{\circledR}$ 사로 봉합하여 고정하였다(Fig. 1). 창상의 오염을 방지하기 위해 1 일 1 회의 소독을 시행했다.

\section{2. 체온 측정 방법}

실험에서 사용된 컴퓨터 적외선 체열 감지기는 IRIS2000 (Infra Red Imaging System, Medicore, Seoul, Korea)으로 체표에서 방출되는 적외선을 가시화하여 간 접적으로 표피의 온도를 측정하는 기기이다. 혈류변화에 따른 체표온도의 변화영상은 높은 온도를 나타내는 흰색, 노란색 순으로 온도가 내려갈수록 붉은색, 보라색, 검은 색의 색조의 스펙트럼을 보여 온도의 변화를 쉽게 시각적 으로 인식할 수 있다.

가토의 하복부 피판에 대해서 거상된 피판을 다시 제자 리에 고정한 다음 24 시간이 경과한 시점에서 컴퓨터 적외 선 체열 감지기로 입체각이 $90^{\circ}$ 가 되고, 측정거리는 30 
$\mathrm{cm}$ 가 되도록 하여 피판의 체표온도를 측정하였다. 피판 의 술 후에 나타나는 영상 색조의 변화에 대해 일차적으로 시각적 평가를 시행하였다. 8도 이상의 온도 저하가 있을 경우 유의한 괴사가 일어난다는 이승훈 등의 연구결과에 착안하여 8도 이상의 온도 차이를 보이는 범위를 예상 괴사 범위로 설정하였다. ${ }^{7}$

\section{3. 피판의 생존 면적 평가 및 체열 감지기 영상과의 비교 분석}

피판 거상 2주일 후 피판의 생존 범위를 육안으로 확인 하였다. 짙은 가피로 덮여 있는 소견을 보이는 부위를 괴사된 범위로 판정하였다. 전체 피판 면적에 대한 생존부 분의 정량적 평가를 위해 표준화된 디지털 영상 $(550 \mathrm{~d}$; Canon, Tokyo, Japan)을 촬영하였다. 디지털 영상 분석 프로그램(Image J, NIH, Bethesda, MD)을 이용하여 평 균 생존 면적을 계산하였으며 술 후의 체열 감지기상 온도 변화에 따른 영상 중 섭씨 8도 이상의 온도저하를 보이는 부분과 디지털 카메라로 촬영한 영상 중 짙은 가피로 덮인 부분을 겹쳐 그 범위의 일치 정도를 확인하였다.

\section{4. 통계 분석}

통계 분석은 정규성 검정을 통해 자료가 정규분포함을 확인하였으므로 paired T-test를 사용하였다.

\section{결 과}

피판 거상 후 24시간이 지난 시점에서 축성 피판의 체표 온도를 컴퓨터 적외선 체열감지기로 측정한 결과, 8 례 모두에서 혈관경이 절단된 우측 피판에서는 파란색 또는 보라색 등의 낮은 온도를 나타내는 컬러 영상을 보여 피판 의 혈류가 불량함을 확인할 수 있었다. 혈관경에 가까울수 록 더 높은 온도의 영상인 붉은색을 나타냈으며 좌측의 정상 혈행을 보이는 피판에서 중앙부를 경유해 혈관경이 절단된 쪽으로 혈류가 있음을 체온영상으로 확인할 수 있었다.

술 후 2주일째 창상의 치유 후 피판 괴사 부위는 육안으 로 확연하게 보였다. 짙은 가피로 덮여있는 부분을 괴사된 부위로 설정하고 전체 피판에 대한 생존 면적을 평가한
(A)

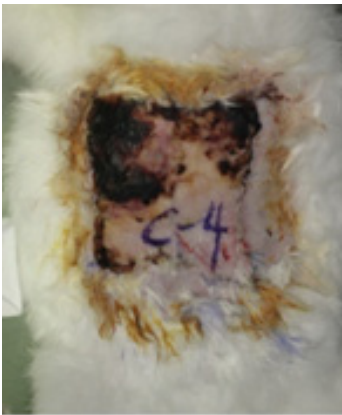

(B)

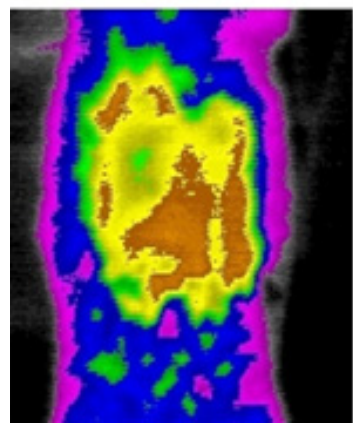

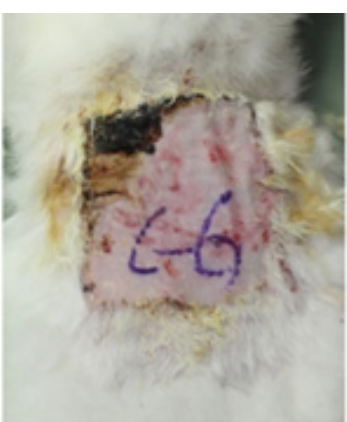

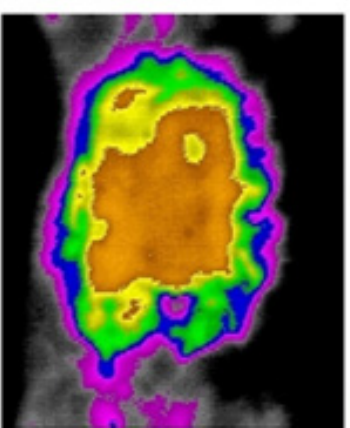

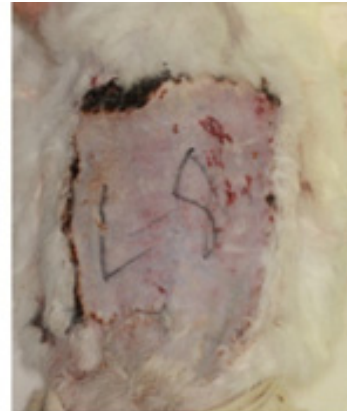
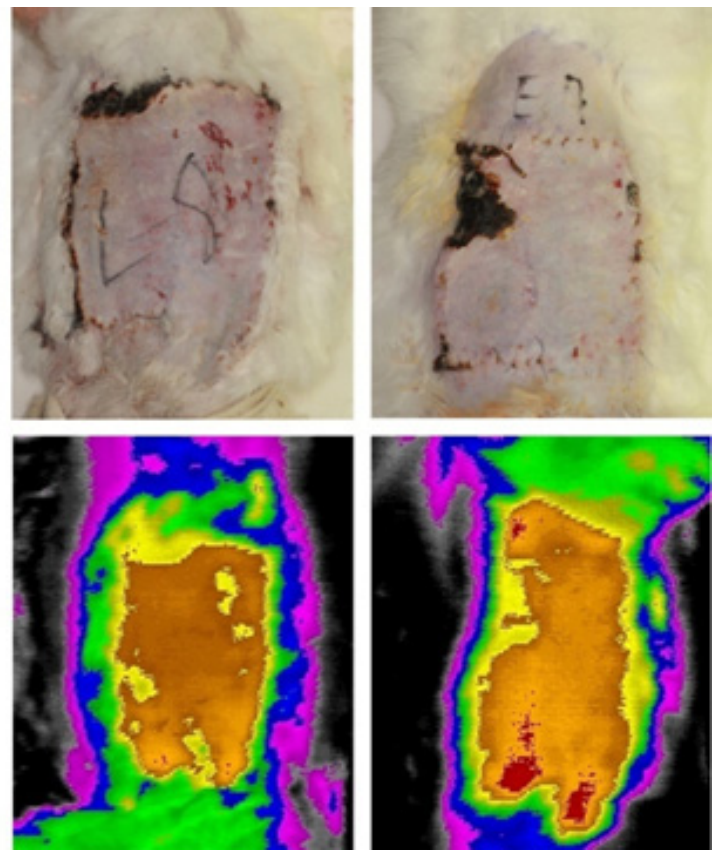

Fig. 2. Post operative 2 weeks view. (A) Flap shows definite distal necrosis with black eschar, its DITI scan (B) which showed color image that higher temperature as more similar to red color. The yellow colored area matched with distal necrotic area of the flap. 
(A)

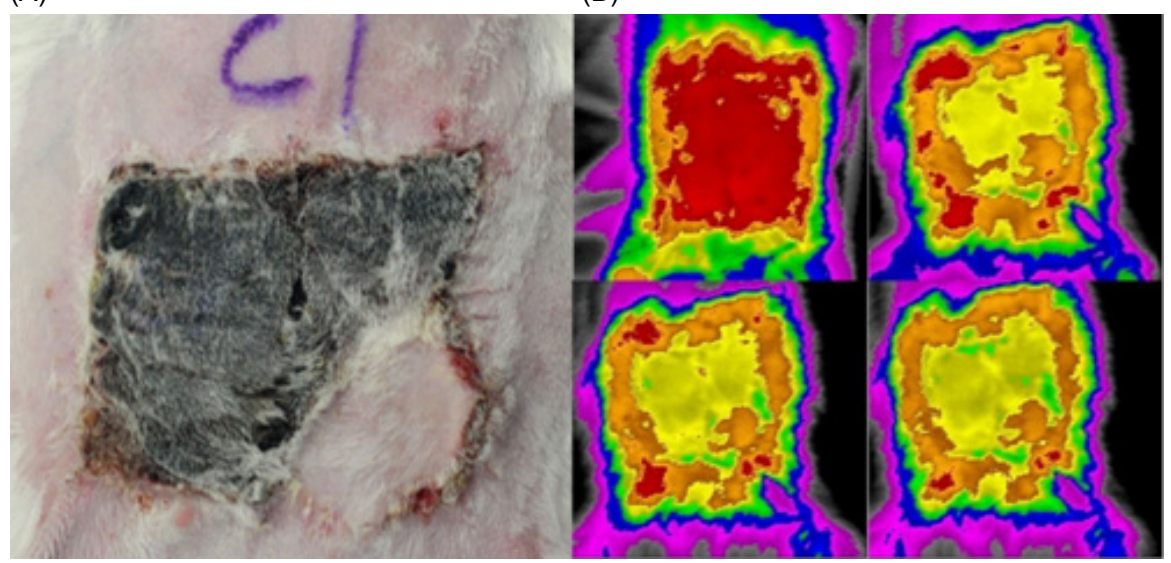

Fig. 3. DITI scan change for pre-operation, POD1, POD7, POD14. (A) Flap image after 2 weeks from surgery, (B) (from left upper to clockwise rotation) which shows DITI scan for pre-operation, POD1, POD7, POD14, there is no significant color change from POD1 to POD14.

Table 1. Comparison of expected survival area by DITI and measured survival area

\begin{tabular}{cccc}
\hline Case & Expected survival area by DITI (\%) & Measured survival area (\%) & Accordance rate \\
\hline 1 & 59.0 & 64.0 & 91.5 \\
2 & 74.6 & 67.1 & 89.9 \\
3 & 39.8 & 37.4 & 94.0 \\
4 & 50.4 & 58.0 & 85.2 \\
5 & 71.9 & 79.0 & 90.1 \\
6 & 33.6 & 34.0 & 98.6 \\
7 & 40.5 & 36.2 & 89.6 \\
8 & 72.9 & 74.2 & 98.2 \\
Average & 55.3 & 56.2 & 92.1 \\
\hline
\end{tabular}

Table 2. Statistical analysis by paired T-test

\begin{tabular}{ccc}
\hline & $\begin{array}{c}\text { Expected survival } \\
\text { area by DITI (\%) }\end{array}$ & $\begin{array}{c}\text { Measured survival } \\
\text { area (\%) }\end{array}$ \\
\hline $\begin{array}{c}\text { Mean SD } \\
P \text {-value* }\end{array}$ & $55.3(16.6)$ & $56.2(18.0)$ \\
\hline
\end{tabular}

* Statistical significance was evaluated by paired T-test.

결과 평균 $56.2 \pm 16.8 \%$ 를 보였다.

술 후의 체열 감지기상 온도변화에 따른 영상 중 섭씨 8도 이상의 온도저하를 보이는 부분과 디지털 카메라로 촬영한 영상 중 짙은 가피로 덮인 부분의 그 범위의 일치 정도를 확인한 결과 평균 $92.1 \%$ 의 일치율을 보였다(Fig. 2, Fig. 3). 또한 컴퓨터 적외선 체열 감지기를 이용하여 예상한 피판의 생존 범위와 피판 거상 2 주일 후 육안으로 관찰한 피판의 생존 범위의 퍼센트 평균 및 표준편차가 각각 55.3 (16.6), 56.2 (18.0)로, 두 결과의 통계적 차이는
없는 것으로 나타났다(Table 1, Table 2).

\section{고 찰}

피판 괴사는 공여부의 손실과 반흔, 수혜부의 이차 수술 등의 문제를 야기한다. 피판 괴사의 주요한 내적 요인은 부적절한 혈류공급과 관련이 있다. 피판의 혈관경에 문제 가 발생하여 허혈이 생기면 피판의 괴사가 일어난다. 허혈 이 발생하고 96시간 이상 지난 후 재관류를 시행할 경우 피판의 생존은 기대하기 어렵다고 알려져 있다. ${ }^{10}$ 따라서 수술 초기에 피판의 혈류 상태에 대한 지속적인 평가가 필요하다.

피판 혈류 상태에 대한 평가 방법 중 피판의 색깔, 모세 혈관 재충만, 진피출혈 등은 주관적인 평가이다. 음향도 플러검사(audible Doppler)는 피판경 혈행의 유무를 파 
악하는데 보편적으로 사용되고 있으나, 피판 주위의 다른 혈행과 감별이 용이하지 않을 수 있으며, 작은 피판에서는 지속적으로 측정하기 어렵다. 반면에 레이저 도플러 혈류 측정(laser doppler flowmeter)는 비관혈적으로 연속적 인 측정이 가능하고, 모세혈류를 정확히 측정함으로써 임상에서 많이 이용되고 있다. ${ }^{5}$ 그러나, 레이저 도플러를 이용한 혈류측정은 국소적인 측정이기 때문에 피판이 클 수록 피판 전체의 혈행을 파악하기 어렵고, 그 수치가 상대적이므로 해석의 어려움 때문에 객관적으로 정량화 하기에 부족하다는 단점이 있다. 이런 점에서 이동은 등 ${ }^{11}$ 은 피부형광(dermatofluorometer)의 유용성에 대해 소 개한 바가 있으나, 이 방법도 형광물질을 투여하여 측정해 야 하는 번거로움이 있으며 반복 측정 시 시약을 반복투여 해야 하고, 고가의 장비로 인해 현실적 적용이 어렵다는 단점이 있다. ${ }^{12}$

피판 수술 후 피판의 혈류상태를 혈관 조영 영상처럼 연속적으로 볼 수 있다면 수술 직후 피판이 가지는 취약점 의 조기 극복과 예방에 큰 도움이 될 수 있다. 이에 저자들 은 컴퓨터 적외선 체열 감지기를 이용하여 피판의 혈류상 태를 평가하고자 하였다.

컴퓨터 적외선 체열 감지기는 피부에서 방출되는 에너 지를 기계 내의 감지기가 포착, 증폭시켜 컴퓨터 모니터를 통해 방사선 조사 없이 체열 차이를 컬러 영상으로 나타내 는 방식을 말한다. ${ }^{13}$ 즉, 모든 물체는 열을 방출하는데 신체는 적외선 영역의 열을 방출하므로 이를 적외선 센서 가 감지하여 전기적 신호로 변환하고, 이 변환된 전기신호 를 컴퓨터가 컬러 영상으로 나타내는 방식이다. 이러한 컴퓨터 적외선 체열 감지기는 실험 및 임상적으로 연구되 고 있으며, 인체에서 자연적으로 방출되는 눈에 보이지 않는 파장의 적외선을 촬영하여 통증이 있는 부위나 질병 이 발생한 부위의 미세한 온도 변화를 영상으로 나타내줌 으로써 환자의 증상을 시각화시켜 신체의 이상을 진단하 는 방법으로 사용되고 있다. ${ }^{14-16}$ 또한 방사선학적 검사들 이 해부학적 형태의 변화를 알려주는데 반해 체열 감지기 를 이용한 검사는 신체의 생리적인 기능의 변화를 알 수 있는 장점을 지닌 것으로 보고된다. ${ }^{17}$
컴퓨터 적외선 체열감지기인 IR-2000은 측정되는 온 도가 $1.2^{\circ} \mathrm{C}$ 이하의 편차를 가지는 영상의 경우에서 $0.04^{\circ} \mathrm{C}$ 의 차이를 컬러 영상으로 나타낼 수 있는 민감한 기계로, 저자들은 이를 이용해 피판의 체표온도를 측정하여 피판 의 혈류분포를 지형학적으로 알고자 하였다. 축성 피판을 거상한 후 다시 제자리에 고정한 다음 24시간이 지난 시점 에서 변화된 체온을 컴퓨터 적외선 체열감지기로 측정하 였다. 그 결과 혈관경 근처의 피부온도가 붉은 색으로 나타 났고, 이는 상대적으로 높은 체표온도를 지니고 있음을 나타내었다. 반면 혈관경과의 거리가 멀어질수록 피부온 도가 어두운 색으로 나타났으며 이는 상대적으로 낮은 체 표온도를 가지고 있음을 의미한다. 절단측의 혈관경 근처 의 체온은 비절단측의 혈관경과 유의한 차이가 있었으며 피판의 중앙부에서 건측에서 절단측으로 같은 체온분포가 밝은 컬러 영상으로 연결되어 있음이 관찰되어 중앙을 가 로지르는 혈류의 흐름이 있음을 확인할 수 있었다.

저자들은 피부 온도는 피하혈관의 혈류량에 의해 달라 진다 ${ }^{8}$ 는 사실을 기초로 하여, 피판 생존의 모니터링방식 으로 체열 감지기를 이용한 피판의 예후 예측의 유용성을 평가하고자 하였다. 축성 피판은 피판줄기 내에 사이막 피부동맥에서 분지한 직접 피부동맥이 들어 있는 피판으 로 임의 피판에 비해 더 안전하며 주변 온도의 변화에 영향을 적게 받는 특성이 있다. 또한 영양동맥의 혈관 지배 범위에 따라 다양한 괴사 범위를 보일 수 있으며 혈액 공급 부족에 따른 피판 내 온도 변화와 피판 괴사를 확실히 발생시킬 수 있어 이를 통해 체열 감지기의 영상과 피판 생존의 연관성을 확인하고자 하였다.

실험 결과에 의하면, 축성 피판 거상 후 체표면의 온도 변화에 따른 현저한 색조변화가 체열 감지기를 통해 확인 됐으며 괴사 부위는 피판에서 현저한 색조의 변화를 보였 던 위치와 동일하여 체열 감지에 따른 영상의 변화가 피판 괴사와 연관성이 있음을 확인하였다. 실험 개체의 수가 적어 피판 괴사를 초래하는 절대적인 의미의 수치를 나타 내기에는 어려움이 있으나, 부위별 혈류의 변화로 인한 온도 차가 피판 생존과는 연관이 있고, 이러한 온도 차는 색조의 변화로 나타나므로 이를 이용한 체열 감지기의 
피판 내의 혈류량에 대한 온도변화를 육안으로 볼 수 있게 하여 전체적 피판 내의 변화를 파악할 수 있으므로 이를 이용하여 피판 생존의 예측 판정에 도움을 줄 수 있을 것이다.

\section{참고문헌}

1. Hovius SE, van Adrichem LN, Mulder HD, van Strik R, van der Meulen JC. The predictive value of the laser Doppler flowmeter for postoperative microvascular monitoring. Ann Plast Surg 1993;31:307-12.

2. Hwang JW, Park DH. Estimation of the normal skin blood flow by laser Doppler flowmetry. J Korean Soc Plast Reconstr Surg 1996;23:394-404.

3. Jones BM, Sanders R, Greenhalgh RM. Monitoring skin flaps by colour measurement. Br J Plast Surg 1983;36:88-94.

4. Khouri RK, Shaw WW. Monitoring of free flaps with surface temperature recordings: is it reliable? Plast Reconstr Surg 1992;89:495-9.

5. Russell JA, Conforti ML, Connor NP, Hartig GK. Cutaneous tissue flap viability following partial venous obstruction. Plast Reconstr Surg 2006;117:2259-66.

6. van Dam H, Nduka C, Carver N. No touch free-flap temperature monitoring. Br J Plast Surg 2003;56:835.

7. Lee SH, Baek SH, Hwang WJ, Jo DI, Oh JK, Kim JT. Application of ThermalCAMTM P40-Infrared thermographic imaging in the monitoring of survival of lower abdominal random flap in the rabbit. J Korean Soc Plast Reconstr Surg 2004;31:95-101.

8. Rogatto WD. The infrared \& electro-optical systems handbook.
Electro-optical Components. Vol. 3, Ann Arbor: SPIE Press; 1993. p.177.

9. Dunn RM, Mancoll J. Flap models in the rat: a review and reappraisal. Plast Reconstr Surg 1992;90:319-28.

10. Mirzabeigi MN, Wang T, Kovach SJ, Taylor JA, Serletti JM, $\mathrm{Wu}$ LC. Free flap take-back following postoperative microvascular compromise: predicting salvage versus failure. Plast Reconstr Surg 2012;130:579-89.

11. Lee DE, Chung HK, Kim YB, Yang SJ, Park CS. Comparision of assessment of blood flow in flaps with laser Doppler flowmeter and dermatofluorometer. J Korean Soc Plast Reconstr Surg 1995;22:771-80.

12. Cha BH, Kim SK, Kim JT. Estimation of lower abdominal flap survival in rabbit model using laser Doppler flowmetry value. J Korean Soc Plast Reconstr Surg 2002;29:311-7.

13. Kim YW, Kim MR. Diagnostic efficacy of DITI(Digital Infrared Thermographic Imaging) for the dysesthesia of the lower lip \& chin. J Korean Assoc Oral Maxillofac Surg 2002;28:53-60.

14. Gratt BM, Sickles EA. Electronic facial thermography: An analysis of asymptomatic adult subjects. J Orofac Pain 1995;9:255-65.

15. Gratt BM, Shetty V, Saiar M, Sickles EA. Electronic thermography for the assessment of inferior alveolar nerve deficit. Oral Surg Oral Med Oral Pathol Oral Radiol Endod 1995;80:153-60.

16. Biagioni PA, Longmore RB, McGimpsey JG, Lamey PJ. Infrared thermography. Its role in dental research with particular reference to craniomandibular disorders. Dentomaxillofac Radiol 1996;25:119-24.

17. Kruse RA Jr, Christiansen JA. Thermographic imaging of myofascial trigger points: A follow-up study. Arch Phys Med Rehabil 1992;73:819-23. 